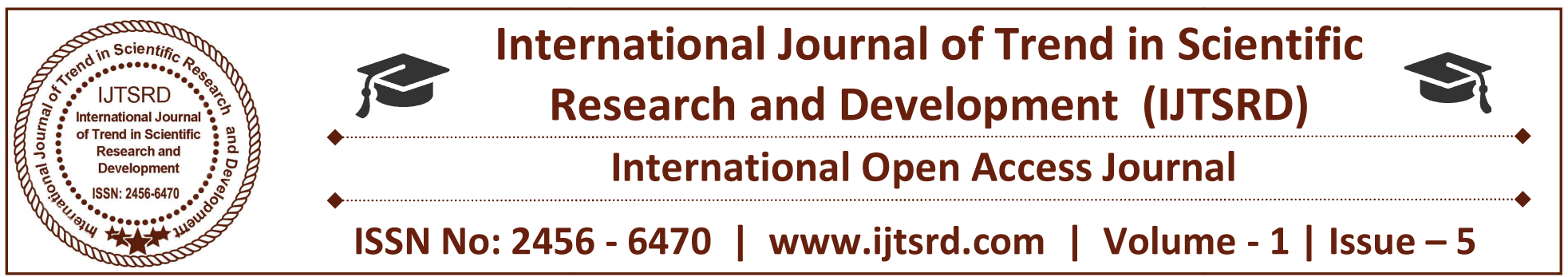

\title{
Stock Market Performance Indicators and Standard of Living in Nigeria - Entrepreneurial Approach
}

\author{
Akpunonu, Uju Evans (Ph D.) \\ Department of Entrepreneurship Studies, \\ Chukwuemeka Odumegwu Ojukwu University \\ (Former ANSU), Igbariam Campus \\ Dim EthelMary O. (Ph D.) \\ Department of Business Administration, \\ Chukwuemeka Odumegwu Ojukwu University \\ (Former ANSU), Igbariam Campus
}

\author{
Obialor, Michael C. (Ph D) \\ Department of Banking and Finance, \\ Chukwuemeka Odumegwu Ojukwu University \\ (Former ANSU) Igbariam Campus \\ Egungwu, Ikenna (Ph D.) \\ Department of Banking and Finance, \\ Chukwuemeka Odumegwu Ojukwu University \\ (Former ANSU), Igbariam Campus
}

\section{ABSTRACT}

The study examined stock market performance indicators and standard of living in Nigeria for the period of 1986 to 2014 . The objectives of the study are to evaluate the contributions of stock market liquidity and new issues (primary) market on the standard of living in Nigeria. The study was structured around an expo facto research design on secondary data sourced from various issues of Central Bank of Nigeria (CBN) Statistical Bulletin, World Development Indicators (WDI), and Nigeria Stock Exchange Factbook. Two models were developed to test the two hypotheses formulated for the study. The models include, standard of living and stock market liquidity, standard of living and primary (new) issues market. Ordinary least square analysis (OLS) was used to test the hypotheses. The result revealed that stock market liquidity and primary (new) issues market have insignificant effect in improving standard of living in Nigeria The study concludes that in spite of the growth potentials of stock market in Nigeria, it has not contributed meaningfully to improvement of the standard of living of an average Nigerian. The study recommends among others that more intensified and stock liberalization is required such that will encourage more productive investment, resulting in financial deepening, economic growth and development and improved living standard of the citizens.

Keywords: Stock market, Standard of living, Stock Market Liquidity, Primary (New) Issues Market and Entrepreneur

\section{INTRODUCTION}

Stock market is an economic institution which is expected to promote efficiency in capital formation and allocation and improve the standard of living in the economy. Stock market according to Ifeoluwa and Bolanle (2012) enables entrepreneurs, governments and industries to raise long term capital for financing new projects, expanding and modernizing industrial /commercial concern. Zahid, Ather and Anam (2011) opined that stock market plays a crucial role in global economies and corporate finance where the financial market generates finance for the economic growth of the country. Stock market facilitates the flow of funds from the area of surplus to the area of needs, as well as channeling of funds from those who desire to those 
International Journal of Trend in Scientific Research and Development (IJTSRD) ISSN: 2456-6470

who need them for economic endeavors. This is to say that if capital resources are not properly managed and channeled to productive investment in the country, standard of living will be negatively affected.

Therefore, the importance of stock market in any economy cannot be over-emphasized because it promotes economic development in all sectors (Nwachukwu, 2009; Kalu, 2009). In developing economy like Nigeria, the development and growth of stock markets have been wide spread in recent time. Despite the size and illiquid nature of stock market, its continued existence and development could have important implications for economic activities. (Alajekwu and Achugbu 2012). Such financial activities as it affect stock market includes new issues (primary) market, stock market liquidity; among others. Thus, stock market can induce standard of living by mobilization of resources and channeling investment to various sectors of the economy, thereby making stock markets in most nations of the world become a source of long-term investment to entrepreneurs, groups and government at all levels (Akpunonu and Nwankwo 2014).

Standard of living is a relative measure of the quality of life of a person or group. High standard of living indicates development of an economy, it is important to note that nations who have good financial system have a propensity to develop its economy more quickly and improve the standard of living of the citizenry. Therefore, for capital market (stock market) to contribute to high standard of living and development in Nigeria, it must operate efficiently.

Most researchers like Kolapo and Adaramola (2012), Ewah, Esang and Bassey (2009), Oke and Adwusi (2012), to mention but a few examined stock market development, performance, activities, among others as it affects economic growth using gross domestic product (GDP) as proxy for economic growth revealed that stock market boost economic growth. Despite this stock market laudable performance and benefits, standard of living of the Nigerian citizens is still jeopardized. This study is therefore geared towards examining the degree to which stock market liquidity affects standard of living in Nigeria and assess the extent to which new issues affects the standard of living in Nigeria.

The study hypothesized that:

Stock market liquidity has no significant effect on standard of living in Nigeria and that New issues have no significant effect on standard of living in Nigeria.

\section{REVIEW OF RELATED LITERATURE}

\section{Conceptual Review}

The financial sector of the economy is to serve as the driver and catalyst to achieving the vision and to help attain full diversification of the economy. The idea is to strengthen the domestic financial market by developing competence and skills for financial services industry, improve access to finance and build an integrated infrastructure for the financial industry, create a vibrant capital market and help more Nigerian make more money through the market (Sule and Momoh 2009). The financial market is the medium through which funds are mobilized and channeled efficiently from savers to users. It functions through the interplay of entrepreneurs, individuals, institutions and instrument.

Kolapo and Adaramola (2012) viewed Nigeria stock exchange as one that was to play a key role during the offer for sale of the shares of the affected enterprises According to Ewah, Esang and Bassey (2009) the knowledge of capital market can make a wealthy nation.

\section{Nigerian Stock Market}

Stock market is a market for the trading of company stock. Stock market plays a very crucial role in mobilization and allocation of funds from savers to productive investment such that will spur economic development and improve the standard of living in the economy. Audu and Apere (2013) opined that Stock market facilitates efficient allocation of resources to the appropriate users. It also enhances higher productivity and better realization for macroeconomic goals such as price stability, higher level of savings, greater export opportunities, more 
International Journal of Trend in Scientific Research and Development (IJTSRD) ISSN: 2456-6470

employment opportunities, and a higher standard of living for the populace.

Nigeria Stock Exchange was founded in the year 1960 as the Lagos Stock Exchange with 19 securities listed for trading. There were 262 securities listed on The Exchange, made up of 11 Government Stocks, 49 Industrial Loan (Debenture/Preference) Stocks and 194 Equity/Ordinary Shares of Companies and as at December 31, 2013, it has about 200 listed companies with a total market capitalization of about N12.88 trillion ( $\$ 80.8$ billion). The Nigeria Stock Exchange took on its present name in December, 1977 as by then the Stock Market already had branches in the most important business centers of the nation such as: Lagos Stock Exchange opened and commenced trading in 1961; Kaduna trading floor opened in June 1, 1978; Port Harcourt trading floor opened on April 30, 1980; Kano opened on May 22, 1989; Onitsha opened and commenced trading in February 1990; Ibadan opened in August 1990; Abuja opened on October 14, 1999 and commenced remote trading on Automated Trading System (ATS); Yola opened on April 13, 2002; Benin opened on January 27, 2005; Uyo opened on May 26, 2007; Abeokuta Exchange commissioned Electronic Trading Floor on Nov. 17, 2008; Owerri Exchange commissioned Electronic Trading Floor on February 6, 2009. Lagos however remained the headquarters of the Nigeria Stock Exchange. The business of trading in Nigeria stock exchange market is conducted during the weekdays and the goods which are kept as security while trading are; corporate bonds, shares and government bonds between $9.30 \mathrm{am}$ and $2.30 \mathrm{pm}$. The trading of shares and bonds are done by the stock brokers (nigeriastockonline, Wikipedia, Egungwu 2013, Audu and Apere 2013, Nigeria Stock Exchange Factbook 2013/2014).

Nzotta (2004),viewed that Nigeria Stock Exchange was to carry out the following objectives: provision of facilities to the public for the purchase and sale of funds, stocks and shares of any kind and for the investment of money; to control the granting of a quotation on the stock exchange in respect of funds, stocks and shares of any company, government, municipality local authority and other corporate body; to regulate the dealings of members, their interest and those of their clients; to promote, support or propose legislative or other measures affecting the aforementioned objects.

\section{Standard of Living (SL)}

Standard of living according to English dictionary is a relative measure of the quality of life a person or group has. Parliamentary Post (2015) refer living standard as households' level access to goods, services and recreational activities. Wikipedia viewed standard of living as the level of wealth, comfort, material goods and necessities available to a certain social economic class in a certain geographical area. Factors to consider in standard of living include income, availability and quality of employment, class disparity, poverty rate, quality and affordability of housing, gross domestic product, inflation rate, affordable healthcare services, literacy rate, infrastructure, national economic growth, economic and political stability among others.

Standard of Living (SL): This is proxied by per capita GDP. Economic growth and per capita GDP are crucial -and strongly linked - determinants of stock market development. Higher economic growth rates allow more people to invest in shares. A rise in per capita income increases an individual's ability to save or invest. However, the increase in per capita income should be considered with caution, for individuals will only invest after satisfying their basic needs. That is to say that a sizeable per capita increase in income - if realized from a low base - will be largely directed towards more consumption, and thus will not significantly increase investment, if it does so at all (Roc, 1996). In other words, it is not only the increase in per capita GDP that matters, but also - and perhaps even to a greater extent - the level of the per capita GDP. Greater individual financial wealth and positive economic prospects bring about changes in saving and investment habits as well as in risk-sharing behaviour of individual households. In their search for higher returns, individuals may shift from deposits into bank accounts to investment in shares. 
International Journal of Trend in Scientific Research and Development (IJTSRD) ISSN: 2456-6470

Standard of living is not just about economic growth but about people and their well being. Standard of living is all about improving people's lives. It is very necessary to enhance lives of the populace because people are the main reason for economic performances. Poverty reduction, per capita income, comfortable house, uninterrupted power supply, quality food, good car, access to health care services, good roads, quality education and most importantly unemployment among others are all components of standard of living.

\section{Stock Market Liquidity}

Stock market liquidity states the degree to which stock can be converted into cash without actually affecting the value. The stock market plays a major role as an economic institution which enhances the efficiency in capital formation and allocation. It enables entrepreneurs, corporations and the government to raise long-term capital which enables them to finance new projects and expand other operations.

\section{Primary (New) Issues Market.}

Nigeria, like many countries has a formal capital market symbolized by existence of a stock exchange and an active new issues market. The market consists of the primary and the secondary segments. The primary segments deal with new issues. It is a market where new securities are issued. The mode of offer for the securities traded in this market include offer for subscription, right issues, offer for sales, private placement. The secondary market trades on already existing securities. Securities in both markets comprise both debt and equity instruments.

New issues are offerings of securities from a company going public for the first time. Initial Public Offerings, or IPOs, are the most commonly known new issues. An IPO is a company's first sale of stock to the public. Securities offered in an IPO are often, but not always, those of young, small companies seeking outside equity capital and a public market for their stock. Investors purchasing stock in IPOs generally must be prepared to accept very large risks for the possibility of large gains. IPO's by investment companies (closed end funds) usually contain underwriting fees which represent a load to buyers. New Issues can also include a secondary offering, which involves the additional sales of securities of companies that have already gone public.

New issue prices are determined by the stock brokers and issuing houses. Supporting this, Opara, Emenike and Ani (2015), reported that following the deregulation of the Nigeria Exchange Market in 1993, prices of new issues are determined by the issuing houses and stockbrokers. Aregbeyen and Mbadiugha (2011) states that securities in both markets comprise both debt and equity instruments and equity market is subdivided into first and second tier security markets.

Primary market deals with the sale of new issues or initial sale of securities to the public. Entrepreneurs, companies, government and public sectors can obtain funds through the sale of new stock through primary market thus improve the standard of living of the citizens. Supporting this, Abosede and Oseni (2011) disclosed that new issues are made primarily to raise additional funds for expansion, diversification, acquisition of information technology, infrastructures and others. Quoted companies could seek expansion of funds through the issuance of supplementary securities in this market while new companies are required to go public before they could issue securities to the public through the market.

\section{Theoretical Framework}

Financial activities have been assumed and are expected to play a very crucial role in the Nigeria Stock Market and thus improve the standard of living of the populace.

The framework of this study revolves around the neoclassical growth framework. The theory believes that a developed financial sector encourages economic growth and development. Anyanwu (2010) in alliance to the theory opined that a well functioning financial systems are able to mobilize household savings, allocate resources efficiently, diversify risks, induce liquidity, reduce information and transaction costs and 
International Journal of Trend in Scientific Research and Development (IJTSRD) ISSN: 2456-6470

provide an alternative for raising funds through individual savings and retained earnings. Stock market reforms therefore should trigger economic growth and development such that will improve the standard of living of the economy. According to Ibenta (2010), if the result of economic growth is equitably distributed among the population, economic development and improvement of standard of living will follow.

\section{Empirical review}

Ifeoluwa and Bolanle, (2015), examined the impact of stock market liquidity on economic growth of Nigeria between the years 1980 and 2012. With the use of Eviews 5.0 econometric software, test for stationary using the Augmented Dickey-Fuller approach was carried out. Ordinary least square technique was employed for the analysis. The result revealed that variables were stationary at their first difference while the Johansen co-integration approach confirmed the existence of co-integrating relationship. The study found that stock market liquidity was not a statistically significant variable in explaining economic growth in Nigeria for the periods under study.

Alajekwu and Achugbu, (2012), investigated the role of stock market development on economic growth of Nigeria using a 15-year time series data from 19942008. The method adopted for analysis is Ordinary Least Square techniques. The result shows that market capitalization and value traded ratios have a very weak negative correlation with economic growth. Recommendation was made that government should make policies that boost the interest of domestic investors in Nigeria in order to spur investors interest and boost stock market activity.

Osho, (2014) examined the Role of Stock Market on Nigeria's Economic Development from 1980 -2010 which covers the market performance and economic growth in Nigeria. The study used ordinary least square of multiple regression estimates with times series data. With the model GDPt as a function of stock market capitalization (MCR) ratio over the time period, value traded ratio (VTR) of domestic stock over the time period, turn over ratio (TOR) over the time period, the findings of the study, revealed that stock market development is positively correlated with the development of financial intermediaries and consequently economic growth. It was therefore, recommended that the fund raised by government inform of government securities in the capital market should be put into productive sector of the economy that will necessitate to growth in all facets of the economy.

Adenuga (2010), investigated the relationship between stock market development and economic growth for the period 1990-2009. The study employed vector error correction model (VECM) technique on the commonly used stock market development indicators such as value to shares traded ratio (vr), market capitalization ratio. The result proposed direct relationship between stock market indicators and economic growth in Nigeria.

Adewuyi and Olowookere (2011) examined the contributions of capital market to economic development in Nigeria using theoretical approach. The result reviewed that stock in trade is money which could be raised through various instruments under well governed rules and regulations carefully administered and followed by different institutions or market operators.

Idowu and Babatunde (2014) evaluated the effect of financial/capital market reforms on economic growth. Using time series data spanning the period 1986 to 2010 which were sourced from the Central Bank of Nigeria (CBN) statistical bulletin, the empirical model was analyzed using Ordinary Least Square (OLS) technique. The analysis revealed that the financial reforms of 1996 impacted significantly on the stock market liquidity. However, credit to the private sector which was used to account for financial intermediary development impacted negatively on the liquidity of the stock market.

Ovat, (2012), investigated empirically into the acclaimed positive role played by stock markets in driving growth, with evidence from the Nigerian stock market. Utilizing several econometric techniques, 
International Journal of Trend in Scientific Research and Development (IJTSRD) ISSN: 2456-6470

such as unit root test, co-integration test and Granger casualty test the study disaggregates stock market liquidity. The essence is to know the aspect of stock market development that is the main driver of growth in Nigeria. The findings suggest the dominance of stock market liquidity over market size is found to have little or no effect on growth. Equally the results suggest a one way causation between financial deepening and growth with causality flowing from financial depending on economic growth.

New issues are concerned with initial issuance and sale of securities (Audu and Apere 2013). Quoted companies can also seek expansion through the issuance of supplementary securities. The effect is multi dimensional as this will result to increased capital flow, employment generation, increase in per capita income and improved standard of living.

Oluwatoyin and Gbadebo (2009) according to Fosback (1991) and Raghbendra Jha (2003), "new issues comprise a category of stocks which fall outside the usual evaluation technique". A new issue can be said to be the first sale of stock by a company to the public. Companies sell their stocks to the public when their physical resources have been utilized to the maximum and they need new capital for expansion and other related purposes. However, the need for this market arises when business prospects become bright and more capital is raised to meet these prospects such that will improve the living standard of the populace.

\section{METHODOLOGY}

\section{Research Design}

This study adopted an ex-post facto and analytical research design. The design type is necessitated by the fact that the macroeconomic variables to be used revolve around issues that are already documented by organised financial institutions.

\section{Sources of Data}

Secondary data were sourced from annual time series of the World Development Indicator, Central Bank of Nigeria (CBN) Statistical Bulletin various issues and
Nigerian Stock Exchange Factbook 2013/2014.covering the period 1986-2014.

\section{Model Specification}

The model specification is based on the Keynesian theory that stock market development engender economic growth. Two models were developed in line with the objectives of the study:

The model is adapted from Osho (2014). The functional relationship of the mode is thus:

$$
\begin{aligned}
& \mathrm{SL}=\mathrm{f}(\mathrm{VTR}, \mathrm{TOR}) \\
& \mathrm{SL}=\mathrm{f}(\mathrm{NI}, \mathrm{CF})
\end{aligned}
$$

The equation can be rewritten as:

$\mathrm{SL}=\mathrm{a}_{0}+\mathrm{a}_{1} \mathrm{VTR}+\mathrm{a}_{2} \mathrm{TOR}+\mu$

$\mathrm{SL}=\mathrm{b}_{0}+\mathrm{b}_{1} \mathrm{NI}+\mathrm{b}_{2} \mathrm{CF}+\mu$

Where: SL = Annual growth rate of Real Per capita income; $\mathrm{VTR}=$ value trade ratio; $\mathrm{TOR}=$ turnover ratio; $\mathrm{NI}=\mathrm{New}$ issues; $\mathrm{CF}=\mathrm{Cost}$ of fund proxied by Prime lending interest rate; $a_{1}, a_{2}, b_{1}, b_{2}$, are the coefficients of the explanatory variables while $a_{0}, b_{0}$ is the constant. $\mu$ is stochastic error term.

\section{Techniques of Analysis}

Preliminary statistical analyses were done using Augmented Dickey - Fuller (ADF) and Philip Peron tests (P-P) to establish the stationarity of data. Johanson Co integration tests were conducted and indicated the existence of a long run relationship among the variables employed for each model tested at $5 \%$ level of significance. Ordinary Least Square (OLS) technique was used for the analyses to test the hypotheses.

\section{DATA PRESENTATION \\ INTERPRETATION OF RESULT}

AND

\section{Hypothesis I}


International Journal of Trend in Scientific Research and Development (IJTSRD) ISSN: 2456-6470

Table 1: Estimated Results of the Stock Market Liquidity Model

\begin{tabular}{|l|r|r|r|c|}
\hline \multicolumn{1}{|c|}{ Variable } & Coefficient & Std. Error & t-Statistic & Prob. \\
\hline VTR & -11.82826 & 145.5921 & -0.081242 & 0.9359 \\
\hline TOR & 73.01306 & 60.85096 & 1.199867 & 0.2410 \\
\hline C & -1.973099 & 3.032369 & -0.650679 & 0.5210 \\
\hline R-squared & 0.120915 & & & \\
\hline F-statistic & 1.788097 & & & \\
\hline Prob(F-statistic) & 0.187242 & & & \\
\hline Durbin-Watson stat & 1.548720 & & & \\
\hline
\end{tabular}

Dependent Variable: SL

Note: $*$ denotes significant at $1 \%, * *$ denotes significant at $5 \% ; * * *$ denote significant at $10 \%$ Source: Authors computation from E-views 8.0

\section{Hypothesis II}

Table 2: Estimated Results of the Stock Market New Issues Model

\begin{tabular}{|l|r|r|r|r|}
\hline \multicolumn{1}{|r|}{ Variable } & Coefficient & Std. Error & t-Statistic & Prob. \\
\hline LOGNI & 1.294890 & 1.353444 & 0.956736 & 0.3491 \\
\hline CF & -0.112836 & 0.429632 & -0.262633 & 0.7953 \\
\hline C & 0.291349 & 11.03112 & 0.026412 & 0.9792 \\
\hline R-squared & 0.049200 & & & \\
\hline F-statistic & 0.569207 & & & \\
\hline Prob(F-statistic) & 0.574090 & & & \\
\hline Durbin-Watson stat & 1.729889 & & \\
\hline
\end{tabular}

Dependent Variable: SL

Note: $*$ denotes significant at $1 \%, * *$ denotes significant at 5\%; *** denote significant at $10 \%$ Source: Authors computation from E-views 8.0

\section{Discussion on Results and Findings}

On Table 1, the result of the estimated Stock Market Liquidity model based on OLS technique was analysed to show the contributions of each of the variables of stock market liquidity (VTR and TOR) on standard of living in Nigeria. The result shows that value traded ratio (VTR) has insignificant negative effect on standard of living ( $\mathrm{P}=0.9359$ and coefficient -11.82826), turnover ratio (TOR) has insignificant positive effect on standard of living in Nigeria $(\mathrm{P}=$ 0.2410 and coefficient 73.01306). The overall result shows that stock market liquidity has insignificant effect on the standard of living in Nigeria.

The coefficient of determination $\left(\mathrm{R}^{2}\right)$ is 0.120915 which indicate that about $12.1 \%$ of changes in standard of living are explained by stock market liquidity indicators (VTR and TOR). The F-statistics explains the overall significance of the variable of stock market liquidity (VTR and TOR) on standard of living (SL). The F-statistics is 1.788097 with 0.187242 probability value which is greater than $5 \%$ level of significance. Based on the F-probability, we 
International Journal of Trend in Scientific Research and Development (IJTSRD) ISSN: 2456-6470

conclude that stock market volatility variables do not have overall significant effect on standard of living in Nigeria. This implies that stock market volatility could not significantly affect the factors that can influence standard of living in Nigeria. The coefficient of Durbin-Watson is 1.548720 and is approximately close to 2 and shows that the model is free of autocorrelation.

On Table 2, the result of the estimated New Issues model based on OLS technique was analysed to show the contributions of each of the variables of new issues (LogNI and CF) on standard of living in Nigeria. The result shows that new issues (NI) has insignificant positive effect on standard of living $(\mathrm{P}=$ 0.3491 and coefficient 1.294890), cost of fund (CF) has insignificant negative effect on standard of living in Nigeria $(\mathrm{P}=0.7953$ and coefficient -0.112836$)$. The overall result shows that primary (new) issues market has insignificant effect on the standard of living in Nigeria.

The coefficient of determination $\left(\mathrm{R}^{2}\right)$ is 0.049200 which indicates that about $5 \%$ of changes in standard of living are explained by new issues market indicators (LogNI and CF). The F-statistics explains the overall significance of the variables of new issues market (LogNI and CF) on standard of living (SL). The F-statistics is 0.569207 with 0.574090 probability value which is greater than $5 \%$ level of significance. Based on the F-probability, we conclude that new issues market variables do not have overall significant effect on standard of living in Nigeria. This implies that new issues market could not significantly affect the factors that can influence standard of living in Nigeria. The coefficient of Durbin-Watson is 1.729889 and is approximately close to 2 and shows that the model is free of autocorrelation.

\section{CONCLUSSION} RECOMMENDATIONS

AND

Based on the findings, the study established that the variables of stock market activities had insignificant effect on standard of living in Nigeria. The study concludes that in-spite of the growth potentials of stock market in Nigeria, it has not contributed meaningfully to improvement in the standard of living of an average Nigerian. Therefore, the study recommends that for a more stable stock liquidity, concerned authorities should institute more monetary and fiscal policies and mechanism that will stabilize some stock market reforms variables in order to promote the stock market and improve the living standard of Nigeria. Government should build and maintain a sound and vibrant stock market by encouraging more companies to go public. By so doing, funds through sale of shares be made available such that will result to increased capital flow for investment by entrepreneurs, generate employment, increased per capita income and affect positively the living standard of Nigerians.

\section{REFERENCES}

Abosede A. J. \& Oseni J. E (2011) Theoretical Analysis of Firm and Market-Specific Proxies of Information Asymmetry on Equity Prices in the Stock Markets Australian Journal of Business and Management Research Vol. 1 No. 2

Adelegan, O. J. (2008). Tax, Investment and Q: Evidence from Firm and Industry level data in Nigeria. International Research Journal of Finance and Economics Issue 16. Retrieved from http://www.eurojournals.com/finance.htm.

Adewuyi, I.D. \& Olowookere, J.K. (2011) The Contributions of Capital Market to Economic Development in Nigeria. International Journal of Economic Development, Research and Investment, Vol. 2 No. 1.

Akpunonu U. E. \& Nwonkwo C. K. (2014) The Effect of Global Financial Crisis on Nigeria Stock Market. COOU Interdisciplinary Research Journal Vol. 1, No. 1

Alajekwu, U. B \& Achugbu, A. A (2012) The Role of Stock Market Development on Economic Growth in Nigeria: A Time Series Analysis an International Multidisciplinary Journal, Ethiopia Vol. 6 (1),Serial 
International Journal of Trend in Scientific Research and Development (IJTSRD) ISSN: 2456-6470

No 24 ISSN 1994-9057 (Print) ISSN 2070-0083 (Online).

Anyanwu C.A. (2010) An Overview of Current Banking Sector Reforms and the Real Sector of the Nigerian Economy Central Bank of Nigeria Economic and Financial Review Volume 48/4.

Aregbeyen, O. \& Mbadiugha, S.O (2011) Factors Influencing Investors Decisions in Shares of Quoted Companies in Nigeria. Social Sciences 6 (3): 205-212 ISSN: 1818-5800.

Audu, N.P. \& Apere, O.T (2013) Factors Affecting the Efficient Performance of the Nigerian

Capital Market. International Journal of Research in Social Sciences Vol. 3, No. 1. ISSN 2307-272X

Ewah, S. O. E., Esang A. E. \& Bassey J. U. (2009) Appraisal of Capital Market Efficiency on Economic Growth in Nigeria. International Journal of Business and Management Vol 4, No. 12

Ibenta S.N.O (2000) Nigeria Money and Capital Market: Theory and Practice, Lagos, Afribase.

Kolapo F.T. \& Adaramola A.O. (2012) The Impact Of The Nigerian Capital Market on Economic

Growth. International Journal of Developing Societies. Vol. 1 No. 1, 2012, 11-19

Idowu, A. \& Babatunde, M.A. (2014): An Evaluation of The Effect of Financial Reforms on Liquidity of The Nigerian Stock Market. International Journal of Economics, Commerce and Management United Kingdom Vol. II, Issue 9, ISSN 23480386

Ifeoluwa I. O. \& Bolanle D. M. (2015) Stock Market Liquidity and Economic Growth In Nigeria. Journal of Economics and International Business Management Vol. 3 1:1-13, ISSN: 2384-7328.

Kehinde, J.S, Yusuf, B. R. \& Abata, M. A.(2012) Market Capitalization Volatility: Effects on the
Nigerian Economic Growth British Journal of Acts and Social Sciences, ISSN:2046-9578,Vol.4 No. 2

Kolapo, F. T. \& Adaramola A. O. (2012) The Impact of Nigerian Capital Market on Economic Growth International Journal of Developing Societies Vol. 1, No. 1, 11-19

Nzotta S.M. (2004) Money, Banking \& Finance: Theory and Practice. Hudson-Jude Nigeria Publishers Owerri Nigeria.

Nigerian Stock Exchange FactBook (2013/2014).

Opara ,C.C, Emenike, K. O \& Ani, W. U (2015) Behaviour of Nigeria Financial Market Indicators: Evidence From Descriptive Analysis. American Journal of Economics, Finance and Management Vol. 1, No 5: 421-429.

Osho, A. E (2014) The Role of Stock Market on Nigeria's Economic Development International Journal of Scientific and Research Publications, Volume 4, Issue 4, ISSN 2250-3153.

Ovat O. O.(2012) Stock Market Development and Economic Growth in Nigeria: Market Size versus Liquidity. Canadian Social Science Vol.8 No.5,71-77.

Post Note (2015) Measuring Living Standards House of Parliament: Parliamentary office of Science \& Technology. No. 491.

Sule, K. O \& Momoh, C. O (2009) The Impact of Stock Market Earnings on Nigerian Per Capita Income African Journal of Accounting, Economics, Finance and Banking Research Vol. 5 No. 5

Zahid, A., Ather, A. K., \& Anam, T. (2012) Stock Market Development and Economic Growth: A Comparative Study of Pakistan and Bangladesh African Journal of Business Management Vol. 6(8) 2985-2989 